\title{
Microplastic Exposure through Mussels Consumption in the Coastal Area Community of Pa'lalakkang Village, Galesong, Takalar District
}

\author{
Nano Hajra El ${ }^{1 *}$, Anwar Daud ${ }^{1}$, Akbar Tahir $^{2}$, Anwar Mallongi $^{1}$, Hasnawati Amqam $^{1}$, Abdul Salam $^{3}$ \\ ${ }^{\mathrm{T}}$ Department of Environmental Health, Faculty of Public Health, Hasanuddin University Indonesia \\ ${ }^{2}$ Department of Marine Sciences, Faculty of Marine and Fisheries Sciences, Hasanuddin University Indonesia \\ ${ }^{3}$ Department of Nutrition, Faculty of Public Health, Hasanuddin University Indonesia
}

\section{*Corresponding Author}

Nano Hajra El

\author{
Article History \\ Received: 16.09 .2020 \\ Accepted: 24.09.2020 \\ Published: 27.09.2020
}

\begin{abstract}
The habit of people disposing of solid waste, especially plastic type waste in the marine environment is the cause of the discovery of microplastic content in seawater. Microplastics with very small sizes can enter the body of marine life, such as mussels. This situation will form the food chain system. This study aims to analyze microplastic exposure through consumption of mussels in communities in the coastal area of Pa'lalakkang Village, Galesong, Takalar District. This research is a type of qualitative research with a descriptive approach. The human sample in this study amounted to 30 respondents, and the environmental sample was 20 mussels with tofu mussels. Data obtained by interview using questionnaires and food pictures, weight measurement, examination of mussels samples in the laboratory, identification of polymer types using FTIR spectroscopy, and documentation. The data obtained were then analyzed descriptively to describe the intake of mussels containing microplastics by the community. The results showed that the average concentration of microplastics found in mussels was 6.7 items/mussels, with Polystyrene polymer content. This proves that people have been directly exposed to microplastics through consumption of mussels. It is known that the average intake of mussels by the community is $91 \mathrm{~g} /$ day, with an average exposure frequency of 96 days/year.
\end{abstract}

Keywords: Exposure, Microplastics, Mussels, Polystyrene.

\section{INTRODUCTION}

Plastic is one of the materials most widely used by humans with a very wide application, both in daily activities and in commercial terms. Plastic pollution is still a big problem in marine and coastal areas in various parts of the world. The characteristics of plastics that are lightweight, durable, strong, flexible and low production cost make plastic production increase significantly every year [7].

Plastics Europe Data [16] states that world plastic production reached 348 million tonnes in 2017, where East Asia is the region with the fastest growing plastic waste production in the world. Indonesia is the largest contributor to marine plastic waste after China and contributes 0.48-1.29 million metric tons of plastic per year [10].

There are many types of plastics produced globally but generally are dominated by 6 types of plastic polymers, namely polyethylene, polyprophylene, polyvinyl alcohol, polystyrene, and polyethylene terephthalate. Plastic polymers that are widely used today are very resistant to degradation, the entry of persistent and complex materials and have a risk to human health and the environment [7].

Microplastics are plastic particles $<5 \mathrm{~mm}$ in diameter which is the upper limit for research purposes [8]. Microplastics have been found in almost all marine habitats around the world. The distribution of microplastics depends on environmental conditions including, ocean currents, combined horizontal and vertical, combined wind and biofilm formation and the nature of the polymer [12].

Copyright @ 2020: This is an open-access article distributed under the terms of the Creative Commons Attribution license which permits unrestricted use, distribution, and reproduction in any medium for non commercial use (NonCommercial, or CC-BY-NC) provided the original author and source are credited. 
Microplastics can accumulate various organic and inorganic contaminants in water. Microplastics also act as carriers of adhering heavy metals and as pollutants and other chemicals that can affect the normal physiological functions of aquatic organisms and can also trigger a series of toxic effects [11]. The toxic effect of plastic particles is indicated due to the plastic itself, after the release of persistent organic pollutants adsorbed by the plastic, and due to the washing process of plastic additives [2]. The level of microplastic toxicity depends on its size, namely the smaller the plastic particles, the greater the toxicity of the chemicals released in marine organisms [4].

Microplastics with very small sizes can enter the body of marine life, such as fish and mussels. This situation will form a food chain system [23]. The presence of microplastics in marine biota species for human consumption and the high consumption of seafood such as fish and mussels raises concerns about the negative impact of microplastics on human health [6].

Investigation of the potential risks associated with the particles suggests that it is possible that some of the smaller plastic particles can pass through the intestinal wall and translocate to tissues far from the mucosa [22]. Micrometer-sized plastic absorption will be easier to digest, but nanometer-sized plastic can pass through cell membranes [12].

The contamination of the Takalar sea is evidenced by the presence of garbage in the sea and waters of Takalar Regency, namely on the three beaches that are the research locations, found solid waste which is dominated by plastic type waste [20]. Thus the aim of this study was to analyze microplastic exposure through consumption of mussels in the coastal area of Pa'lalakkang Village, Galesong, Takalar District.

\section{Material ANd Methods \\ Location and research design}

This research was conducted in Pa'lalakkang Village, Galesong, Takalar District. This type of research is qualitative research with a descriptive approach.

\section{Population and sample}

The human population in this study is people who live in the coastal area of Pa'lalakkang Village and the environmental population is the type of sea shell that is consumed by the people in the Beba Fish Landing Site. Human samples as many as 30 people, with criteria for consuming sea mussels. Environmental samples were 20 sea mussels, with the dominant type of mussels consumed by the community and the selection of mussels was done by purposive sampling.

\section{Data collection}

Data collection methods used in this study were interviews using questionnaires and food pictures, examination of mussels samples in the laboratory, and identification of polymer types using FTIR spectroscopy and documentation.

\section{Data analysis}

The data analysis used in this research is descriptive analytic, which is to describe the intake of mussels containing microplastics by the community.

\section{RESULTS}

\section{Characteristics of Respondent}

Table-1: Characteristics of Respondents

\begin{tabular}{|c|c|c|c|}
\hline Variable & Category & Frequency & \% \\
\hline \multirow{3}{*}{$\begin{array}{c}\text { Age } \\
\text { (Year) }\end{array}$} & $<30$ & 5 & 16,7 \\
\cline { 2 - 4 } & $30-40$ & 11 & 36,7 \\
\cline { 2 - 4 } & $>40$ & 14 & 46,6 \\
\hline \multirow{2}{*}{ Gender } & Female & 30 & 100 \\
\cline { 2 - 4 } & Male & 0 & 0 \\
\hline Length of stay (Year) & $<30$ & 5 & 16,7 \\
\cline { 2 - 4 } & $30-40$ & 11 & 36,7 \\
\cline { 2 - 4 } & $>40$ & 14 & 46,6 \\
\hline
\end{tabular}

Table 1 shows the characteristics of the people of Pa'lalakkang Village who were respondents in this study. Most $(46,6 \%)$ of the community were over 40 years old, and a small proportion $(16,7 \%)$ of the community were under 
30 years old. Overall $(100 \%)$ respondents in this study were female. Meanwhile, for the length of stay, based on the results of the interview, it was found that all respondents had lived since birth in Pa'lalakkang Village.

\section{Concentration of Microplastics, Intake Rate and Frequency of Exposure}

Table-2: Distribution of Research Variables

\begin{tabular}{|l|c|c|c|}
\hline \multicolumn{1}{|c|}{ Variable } & Minimum & Maximum & Average \\
\hline Concentration of Microplastics (items/mussels) & 1 & 15 & 6,7 \\
\hline Intake Rate (g/day) & 75 & 100 & 91 \\
\hline Frequency of exposure (days/years) & 48 & 96 & 93 \\
\hline
\end{tabular}

Table 2 shows the results of laboratory tests regarding the concentration of microplastics found in mussels, where the minimum number of microplastics is 1 item / mussels, the maximum concentration of microplastics is 15 items/mussels, and the average concentration of microplastics is 6,7 items/mussels. Furthermore, based on the identification results of polymer types using Fourier Transform InfraRed (FTIR) spectroscopy, it is known that the microplastics found in mussels contain polystyrene (PS) polymer types.

Table 2 shows the minimum intake rate for mussels by the community, namely $75 \mathrm{~g} /$ day, the maximum mussel's intake rate of $75 \mathrm{~g} / \mathrm{day}$, and the average mussel's intake rate of $91 \mathrm{~g} / \mathrm{day}$. Meanwhile, for the frequency of exposure of people who consume mussels, it is known that the minimum exposure frequency is 49 days/year, the maximum exposure frequency is 96 days/year, and the average exposure frequency is 96 days/year.

\section{DISCUSSION}

The microplastic concentration is the number of plastic particles $<5 \mathrm{~mm}$ in size found in mussels. The existence of microplastics in mussels is caused by contamination of the Takalar sea by plastic waste. This study showed that the average concentration of microplastics found in mussels was 6, 7 items/mussels.

Mussels are a group of slow-moving marine life and settles in a certain habitat so that it can easily accumulate with heavy metals and chemicals around it. Mussels have only a few detoxification enzymes so it is less able to remove toxic substances or chemical compounds from the body [25]. The main factors that cause microplastics to enter the food chain are their small size and color, which are similar to those of marine organisms, such as zooplankton [24].

Tofu mussels are the type of mussels most often consumed by the people of Pa'lalakkang Village. Based on the results of the interview, it is known that people consume tofu mussels 2 to 3 times a week. In this study, an overview of the rate of mussel's intake by the community was obtained, the frequency of exposure to microplastics in the community, and the duration of exposure to the community.

The rate is the number of tofu mussels containing microplastics with styrene compounds that are consumed in a day. The results showed that the average input rate of tofu mussels by the community was $91 \mathrm{~g} / \mathrm{day}$. This is in line with research by Nurlete [14] which states that the average rate affects the risk level of respondents being exposed to lead ( $\mathrm{Pb}$ ) found in blood mussels.

The frequency of exposure is the time of exposure of the respondent to tofu mussels containing microplastics with styrene compounds in units of days/years. The results showed that the respondent's average frequency of exposure was 93 days/year. The higher the frequency of exposure, the higher the risk for respondents who were exposed to microplastics with styrene compounds. Individuals with the same body weight, intake rate, and duration of exposure will have different intakes and risks if the frequency of exposure is different [5].

Based on the research results, it is known that all respondents have lived and settled since they were born in Pa'lalakkang Village. So it can be concluded that the duration of exposure is considered to follow the age of each respondent. Research conducted by Budiarti [2] states that the longer a person is exposed to hazardous substances, the greater the likelihood that health risks will be received. The results of this study are in line with research conducted by Safitri [17] which states that the duration of exposure of respondents who consume green mussels containing cadmium (Cd), although in low concentrations but in the long term can cause health problems.

The results of identification of the type of microplastic polymer in tofu mussels using FTIR obtained the type of polystyrene polymer. Polystyrene is a polymer with styrene monomer and is thermoplastic which when heated at temperatures above $300^{\circ} \mathrm{C}$ will release toxic substances [13]. The presence of polystyrene polymers in the microplastics 
found in tofu mussels probably comes from the many plastic food packages, such as styrofoam, plastic bags, and other plastic packaging that are seen floating on the coast of Takalar.

Styrene is a colorless liquid that is volatile, and at high concentrations can give off a pungent odor. Styrene is mainly produced for the manufacture of glass fibers, pipes, automotive components, and plastic drinking glass. Small amounts of styrene can be transferred to food from styrene-based packaging materials. Food containers containing styrene can be transferred to food and if it lasts for a long time, it will be dangerous to human health. The transfer of styrene from food containers to food can occur due to the presence of hydrophobic additives or additional substances that are insoluble in water but can dissolve in oil [19] and the presence of lipofility properties of food or the ability of chemical compounds to dissolve into foods that have high fat content [1].

Styrene can be absorbed by the body through inhalation, ingestion, and through skin contact. After the absorption process, the styrene is then distributed throughout the body, with the highest rate of accumulation in fat. One source of polystrene is styrofoam, which is the trade name for polystyrene foam, which is a type of polystyrene that is made to expand with n-pentane or carbon dioxide and form heat-protective packaging or containers. Polystyrene is very commonly used as egg containers, plates, bowls and disposable cups [3]. Its use is disposable so that it can be used as garbage at sea.

In general, styrene is a material that can irritate mucous membranes [9]. As in the study of acute health effects after exposure to styrene in drinking water in Spain, gastrointestinal tract disorders were reported, such as abdominal pain and diarrhea [15]. To date, there are no studies that prove the effects of cancer in humans after ingestion of exposure to styrene. So far, the critical effects have been in the form of red blood cell damage and liver damage [21].

Microplastics are thought to reach the gastrointestinal system through contaminated food or through mucociliary cleansing after inhalation, possibly causing an inflammatory response, increased permeability, and changes in intestinal microbial composition and metabolism [18].The possibility arises that the interaction of microplastics and nanoplastics has the potential to cause immunotoxicity, and lead to side effects, such as immunosuppression, immune system activation, and abnormal inflammatory responses [12].

\section{CONCLUSiOnS}

People have been directly exposed to microplastics through consumption of mussels. It is known that the average concentration of microplastics found in mussels is 7,6 items/mussels, with the type of polystyrene polymer. The average intake rate for shellfish by the community is $91 \mathrm{~g}$ /day, with the average frequency of mussel's exposure being 93 days/year.

Microplastics have been found in mussels consumed by the public. Although until now there has been no research that can prove the adverse effects on health due to exposure to microplastics, with this information, it is hoped that the public will be more careful in processing seafood, especially mussels before consumption, so as to prevent microplastic exposure.

\section{REFERENCES}

1. ATSDR. (1992). Toxicological Profile for Styrene. Agency for Toxic Substances and Disease Registry.

2. Bouwmeester, H., Hollman, P, C. H., \& Peters, R, J. B. (2015). Potential health impact of environmentally released micro and nanoplastics in the human food production chain: Experiences From Nanotoxicology, 1-42.

3. Bpom, R.I. (2016). Bahaya styrofoam sebagai wadah makanan dan minuman. http://ik.pom.go.id/v2016/qa/bahayastyrofoam-sebagai-wadah-makanan-dan-minuman. Diakses 3 Juni 2020.

4. Carbery, M., Connor, W. O., \& Thavamani, P. (2018). Trophic Transfer of Microplastics and Mixed Contaminants in the Marine Food Web and Implications For Human Health.

5. Damayanty, S. (2014). Analisis Risiko Logam Berat (Cr, As, dan Hg) pada Sedimen Laut, Ikan dan Kerang Terhadap Kesehatan Penduduk Pesisir Kota Makassar.

6. Gabriel, L., Barboza, A., Vethaak, A, D., Lavorante, B. R. B. O., Lundebye, A., \& Guilhermino, L. (2018). Marine microplastic debris: An Emerging Issue For Food Security, Food Safety and Human Health. Marine Pollution Bulletin, 133 (January), 336-348.

7. Galloway, T. S. (2015). Marine anthropogenic litter. Marine Anthropogenic Litter.

8. GESAMP. (2019). Guildelines for the Monitoring and Assessment of Plastic Litter in the Ocean, 99.

9. Huff, J., \& Infante, P. F. (2011). Styrene Exposure and Risk Of Cancer. Mutagenesis, 26(5), 583-584.

10. Jambeck, J. R., Geyer, R., Wilcox, C., Siegler, T. R., Perryman, M., Andrady, A., \& Law, K. L. (2015). Plastic Waste Inputs from LandIinto the Ocean, 347.

11. Jinhui, S., Sudong, X., Yan, N., Xia, P., Jiahao, Q., \& Yongjian, X. (2019). Effects of Microplastics and Attached 
Heavy Metals on Growth, Immunity, and Heavy Metal Accumulation in the Yellow Seahorse. Marine Pollution Bulletin, 149 (June).

12. Lusher, A. (2015). Microplastics in the Marine Environment: Distribution, Interactions and Effects. Marine Anthropogenic Litter.

13. NIOSH. (2008). International Chemical Safety Cards: Polystyrene. National Institute for Occupational Safety and Health. Updated on 11/25/03. http://www.cdc.gov/niosh/ipcsneng/neng1043.html.

14. Nurlete, M. W. (2014). Analisis Risiko Timbal (Pb) dalam Biota Laut pada Masyarakat Pesisir Kota Makassar.

15. Pena, A. A., Blasco J. N., \&Vazquez, J. L. V. (2003). Acute Health Effects after Accidental Exposure to Styrene from Drinking Water in Spain. Environmental Health: A Global Access Science Source, 2:6.

16. Plastics, Europe. (2018). Plastics - The Facts 2018. An Analysis of European Plastics Production, Demand and Waste Data. Association of Plastics Manufacturers.

17. Safitri, F. Z. (2015). Tingkat Efek Kesehatan Lingkungan Kandungan Logam Berat kadmium (Cd) pada Kerang Hijau (perna viridis) yang dikonsumsi Masyarakat Kaliadem Muara Angke Jakarta Utara Tahun.

18. Salim, S. Y., Kaplan, G. C., Madsen, K. L. (2013). Air Pollution Effect on the Gut Microbiota. Gut Microbes, 5(2), 215-219.

19. Takada, H., \& Karapanagioti, H, K. (2019). Hazardous Chemical Associated with Plastics in the Marine Environment. Springer International.

20. Tahir, A., Werorilangi, S., Isman, F. M., Zulkarnaen, A., \& Massinai, A. (2018). Short-Term Observation on Marine Debris at Coastal Areas of Takalar District and Makassar City, South Sulawesi-Indonesia. Jurnal Kelautan. Spermonde, 4(2): 1-6.

21. USEPA. (1987). Styrene, CASRN 100-42-5. Integrated Risk Information System (IRIS). National Center for Environmental Assessment.

22. WHO. (2019). Microplastics in Drinking-Water. Geneva. Lisensi: CCBY-NC-SA3.OIGO.

23. Widianarko, B., \& Hantoro, I. (2018). Mikroplastik dalam Seafood dari Pantai Utara Jawa.

24. Wright, S. L., Thompson, R. C., \& Galloway, T. S. (2013). The Physical Impacts of Microplastics Marine. Environmental Pollution, 178, 483-492.

25. Yaqin, K., Fachruddin, L., \& Fitriyani. (2018). Efek ukuran panjang cangkang terhadap indeks kondisi, dan kandungan logam timbal kerang hijau (Perna viridis). JPP, 1(2), 27-40. 